\title{
Effect of Coffee Husk Compost and NPS Fertilizer Rates on Growth and Yield of Coffee (Coffea arabica L.) at Haru Research Sub-canter, Western Ethiopia
}

\author{
Gemechu Chali $^{1, *}$, Tolera Abera ${ }^{2}$, Tesfaye Wakgari ${ }^{3}$ \\ ${ }^{1}$ Ethiopian Institute of Agricultural Research, Jimma Agricultural Research Centre, Jimma, Ethiopia \\ ${ }^{2}$ Department of Natural Resource Management, College of Agriculture, Ambo University, Guder, Ethiopia \\ ${ }^{3}$ Ethiopia Agricultural Research Institute, Ambo Agricultural Research Canter, Natural Resource Management Research Process, Ambo, \\ Ethiopia
}

\author{
Email address: \\ chaligeme2008@gmail.com (G. Chali) \\ *Corresponding author
}

\section{To cite this article:}

Gemechu Chali, Tolera Abera, Tesfaye Wakgari. Effect of Coffee Husk Compost and NPS Fertilizer Rates on Growth and Yield of Coffee (Coffea arabica L.) at Haru Research Sub-canter, Western Ethiopia. American Journal of Bioscience and Bioengineering.

Vol. 9, No. 3, 2021, pp. 81-87. doi: 10.11648/j.bio.20210903.14

Received: March 23, 2021; Accepted: June 10, 2021; Published: June 22, 2021

\begin{abstract}
Application of inorganic and organic fertilizers is the cheapest sources for replenishing plant nutrients in agricultural soils. However, selecting the optimum combination of these resources based on soil type and crop species were necessary. In this view, a field experiment was conducted at Haru research sub-center to assess the effect of coffee husk Compost and NPS Fertilizer rates on soil growth and yield and yield components of coffee in 2018/2019 cropping season. The treatments used were the combination of different rates coffee husk compost and NPS fertilizers rate, and laid out in randomized complete block design with three replications. The combined application of coffee husk compost and NPS fertilizers rate were significantly increased plant height of coffee. Coffee husk compost at $\left(7.5 \mathrm{t} \mathrm{ha}^{-1}\right)$ and NPS fertilizer at (50 $\mathrm{kg} \mathrm{NPS} \mathrm{ha}^{-1}$ ) has improved yield of coffee crop. Integrated NPS fertilizer and coffee husk compost with different rates improved coffee yield and yield components. Therefore, the use of $7.5 \mathrm{tha}^{-1}$ coffee husk compost and $50 \mathrm{~kg} \mathrm{ha}^{-1}$ of NPS fertilizer can be the best alternative integrated soil fertility management option in place of the sole application of inorganic fertilizers at study area tentatively. Nevertheless, in order to give conclusive recommendation further research studies are needed for more soil types and coffee crop varieties.
\end{abstract}

Keywords: Coffee Arabica, Growth, NPS Fertilizer, Organic Fertilizer, Yields

\section{Introduction}

Coffee sector is one of the backbones of the economic and social development in Ethiopia [8]. More than 15 million people directly or indirectly depend on coffee value chain for their income and employment, over $50 \%$ of the coffee produced is consumed within Ethiopia [5]. Coffee market is dominated by the three top producing countries Brazil, Vietnam and Colombia [30]. Major coffee production mainly Southern, South Western and Eastern parts of the country (Kaffa, Illubabor, Jimma, Wollega, Sidamo, Gedeo, Yirgachefe and Hararghe) are the chief major coffee producing areas in the country $[6,8]$. The Oromia Regional
National State is the home land of Coffee arabica evidenced by the existence of wild coffee trees in the region with 464,426 ha of total area coverage and 317,316 ton of production per annum [11].

Poor soil fertility is considered to be the major constraint to increased food production in most acid soils of Ethiopian high lands [36]. The use of inorganic fertilizers believed to alleviate the problem of decline in soil fertility; though it can increase crop productions for time being only. But coffee farm state plantation and local farmers have used mainly chemical fertilizers for long time which can cause degrading of soil [26]. On the other hand, high cost of inorganic fertilizers and other agrochemicals along with cost of 
transportation make their use uneconomical for most smallholder farmers [17]. To alleviate this problem of smallholder farmers with growing demands for sustainable agriculture the use of composting technology to excessively available coffee wastes (coffee husks) becoming inevitable for coffee producing areas [10].

Coffee waste product is one of the wastes, producing during coffee crop production, that have been studied by recycling through conventional and vermicomposting methods [1]. Coffee crop production at Haru district produce a large number of coffee-products (coffee husk), amounting to about 500,000 tons per year are depositing without efficient use. Some farmers mix up coffee husk with manure, but this way showed less efficiency. Beside this, untreated coffee husk will spread diseases and pests to next crop. Currently there is a huge interest from regional and federal government to convert by products of coffee crop (for example coffee husk) into usable end products such as compost [15]. It also serves as a guide to adjust or redirect the fertilization program to correct nutritional imbalances to achieve higher crop yield [32].

Adding inorganic fertilizer alone is not sufficient to retain a sufficient soil fertility status level. Moreover, in degraded soil where there is little organic matter, yield response is limited, even if artificial fertilizers are being used [18]. Beside this, coffee husk compost release nutrients very slowly to the plants. On other hand, nutrient content of compost is low as compared to inorganic fertilizers, so compost is usually applied at large rates. Nevertheless, applying large quantity of such material is difficult in smallholder farmers. Hence, an integrated approach, combining coffee husk compost and mineral fertilizer is better strategy for coffee crop production. Integrated soil nutrient management is eco-friendly and cost-effective soil fertility management techniques enable smallholder farmers to overcome many limitations of the soil fertility management techniques [31].The Significantly enhanced yield of crop, water use efficiency and soil chemical properties as compared to the use of only inorganic fertilizers [34].Chemical fertilizer with the compost that produced from coffee husk increased up to $14 \%$ the yield compared with the control in unchanged production input [21]. The combined use of inorganic and organic fertilizers performed better than just organic fertilizers alone in both the mean height and the final height of the coffee seedlings. Moreover, organic and inorganic nutrient sources are able to provide sufficient nutrients for healthy coffee growth [10].

Despite the significant area of coffee production and its contribution in Ethiopian economy with the mean national coffee yield 0.62 tha $^{-1}$ was low [11]. Even though different factors are responsible for low productivity, low soil fertility status is a major concern in the production of coffee crops in the country [28]. Also reported that, most of the nutrients necessary for coffee growth are deficient at Haru [35] Nevertheless, the sources of plant nutrient for Ethiopian agriculture have been limited to Urea and DAP fertilizers which contain only Nitrogen and Phosphorus that may not satisfy the nutrient requirement of crops, respectively [27]. Ethiopian soils lack most of the macro and micro nutrients that are required for sustaining optimal growth and development of crops were reported [23]. These make Ethiopian fertilizer test worse that are below international and regional standards of Agriculture Growth Program [2]. To overcome this situation the Ministry of Agriculture, Ethiopia has been recently introduced a new compound fertilizer (NPS) containing Nitrogen, Phosphorus and Sulfur with the ratio of $19: 38: 7 \%$ of $\mathrm{N}: \mathrm{P}_{2} \mathrm{O}_{5}: \mathrm{S}$. The compound NPS fertilizer has been currently substituted DAP in Ethiopian crop production system as main source of phosphorous Ministry of Agriculture and Natural Resource [19].Therefore, the objective was to determine the effects of coffee husk compost and NPS fertilizer rates on growth and yield of coffee (Coffea arabica L.) at Haru research subcenter, western Ethiopia.

\section{Materials and Methods}

\subsection{Description of the Study Area}

The study was conducted at Haru Agricultural Research Sub- Center which is located at a distance of $466 \mathrm{~km}$ from Addis Ababa within the Oromia National Regional State. Haru Agricultural Research Sub-Center is found in Wara Baro Kebele Haru district in West Wollega Zone under Jimma Agricultural Research Center at latitude of $8^{\circ} 54^{\prime} 30^{\prime \prime}$ $9^{\circ} 50^{\prime} 30^{\prime \prime}$ North and longitude of $35^{\circ} 52^{\prime} 0^{\prime \prime}-36^{\circ} 8^{\prime} 0^{\prime \prime}$ East. Haru district has $46,451.91$ ha total cultivable land and the total area of land under cultivation at Haru Agricultural Research Sub-Center is about 79 hectares [16].

\subsection{Compost Materials and Preparation Procedures}

Coffee by products (coffee husk), farm yard manure (FYM), top soil, leguminous plant materials, fruit or vegetable wastes, stalk straw, leaves are materials that were used for compost preparation [15]. High quality compost was prepared from a mixture of $70 \%$ coffee pulp, 10\% FYM, $10 \%$ leguminous plant materials and $10 \%$ top soil [24]. Pit site that drain easily so the pile never site in a pool of water was selected. Pit of the size $2 \mathrm{~m}$ length $\mathrm{x} 2 \mathrm{~m}$ width $\times 1.2 \mathrm{~m}$ height was prepared. Often, several pits were dig next to each other, to allow turning from one pit into the next [14].

During compost processing at 21 days the materials were mixed and turned to next pit [24]. The compost was ready for use after three times turning (after 63 days) and after air dried [29]. Good decomposition can be detected by a pleasant odor, heat produced (this was even visible in the form of water vapor given off during the turning of the pile), growth of white fungi on the decomposing organic material, earthy smell, reduction of volume and by the change in color of the materials to brown. Finally, the composts prepared were air dried and incorporate compost to soil in the early spring at a depth of $1-2 \mathrm{~cm}$ of compost into the top $2-4 \mathrm{~cm}$ of soil.

\subsection{Experimental Treatments and Design}

The experiment was laid out in randomized complete 
block design with three replications. The treatment consists of combination of recommended coffee husk compost and NPS blended fertilizers recommended by [12] and [4], respectively. The experiment consists of nine treatments combinations with three replications. The following nine treatment combinations were evaluated.

Table 1. Treatment combinations and their rates.

\begin{tabular}{ll}
\hline Treatment & $\begin{array}{l}\text { Treatment combinations (coffee husk compost in t ha } \\
\text { + NPS in } \mathbf{~ k g ~ h a}^{-1} \text {, respectively) }\end{array}$ \\
\hline T1 & $10+0$ \\
T2 & $0+100$ \\
T3 & $2.5+100$ \\
T4 & $5+75$ \\
T5 & $5+50$ \\
T6 & $7.5+50$ \\
T7 & $7.5+25$ \\
T8 & $10+25$ \\
T9 & $0+0$ \\
\hline
\end{tabular}

\subsection{Data Collection}

At Haru agricultural research sub-center usually yield and growth parameters are collected when coffee cherry is fully ripening or when it is ready for picking. Coffee yields and other agronomic parameters (Coffee yield, plant height, stem diameter, number of branches, number of bearing branches, canopy diameter) were taken from the two central rows per each plot from 12 coffee trees. For coffee yields determination each cherry was picked at a time, collected in baskets, and transferred to bags, after which it was weighed and transported to wet processing. Plant height was measured in meter from the ground level to the top of the plant at physiological maturity from central row of five randomly selected plants per each plot. Further, stem diameter (girth) was measured from middle of the base of plant from central row of five randomly selected plants per each plot by caliper, number of branches was counted and recorded from the whole plant of five selected coffee tree, and numbers of bearing branch from each plot sample were recorded by counting the bearing branches from the coffee tree.

\subsection{Statical Analysis}

Agronomic data was subjected to analysis of variance using GLM procedures of the Statistical Analysis System Software (version 9.3) [22]. Whenever the ANOVA detects significant differences $(\mathrm{P}<0.05)$ between treatments, mean separation was conducted using Least Significant Difference [25].

\section{Results and Discussions}

\subsection{Effect of Treatments on Growth Parameters of Coffee}

\subsubsection{Plant Height}

The mean plant height of coffee was significantly ( $p<$ 0.05 ) affected with integrated application of NPS fertilizer rate and decomposed coffee husk (Figure 1). The maximum plant height $(225 \mathrm{~cm})$ of coffee was recorded from application of $50 \mathrm{~kg}$ NPS ha $\mathrm{h}^{-1}+7.5 \mathrm{t}$ coffee husk compost ha ${ }^{-1}$. While the lowest plant height $(196 \mathrm{~cm})$ of coffee height was obtained from the control. Coffee height recorded for combined fertilizer applications was higher than for that of lonely applied organic or inorganic fertilizers. The increased plant height of coffee over the control in response to the mixed application of the fertilizers might be attributed to the released major nutrients and improved soil physical property in enhancing plant growth owing to their contribution to enhanced cell division, stem elongation, promotes leaf expansion and vegetative growth of plants [20]. Similarly, reported that combining inorganic and organic fertilizers performed better than just organic fertilizers alone in both the mean height and the final height of the coffee seedlings [10].

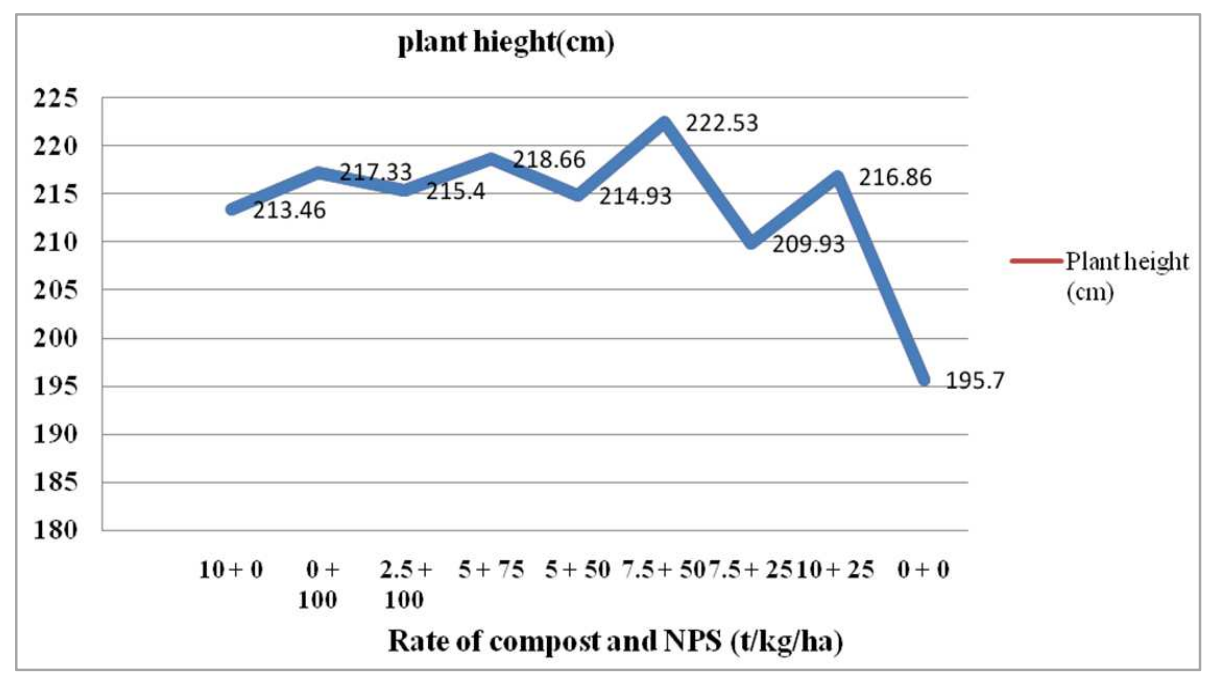

Figure 1. Effects of compost and NPS fertilizer on plant height.

\subsubsection{Number of Branches per Plant of Coffee}

The number of branches plant ${ }^{-1}$ of coffee was nonsignificantly $(\mathrm{p}<0.05)$ affected by application of integrated
NPS fertilizer and coffee husk compost (Figure 2). Whenever results between treatments are non significant application of $10 \mathrm{t}$ coffee husk compost ha $^{-1}$ produced the highest number of branches 49 . While the least number of branches plant ${ }^{-1}$ of 
coffee was recorded from control [34]. This might be due to positive effect of compost fertilizer on soil physical properties and on availability of major nutrients for coffee plant growth. Similarly, reported increase of number of branches per plant of coffee due to application of compost soils [10].

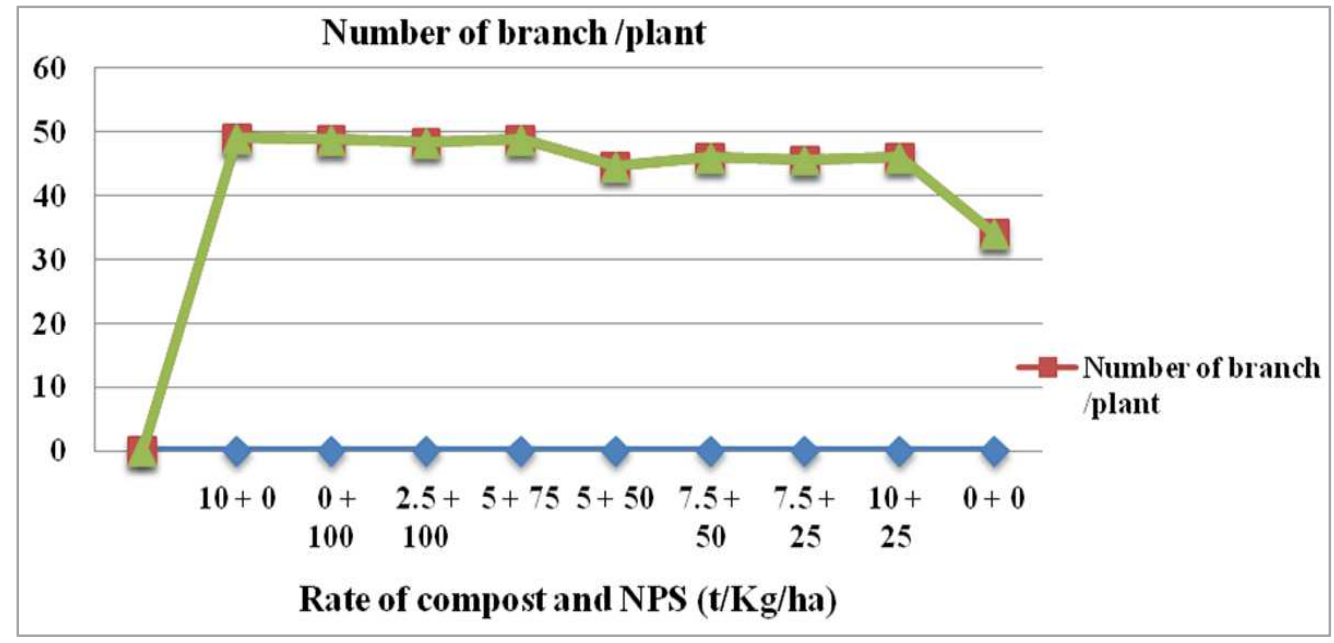

Figure 2. Effects of compost and NPS fertilizer on number of branch/plant.

\subsubsection{Girth of Coffee}

The girth diameter of coffee was showed non-significantly $(p<0.05)$ difference due to treatments (Figure 3). Even though value were non-significantly the maximum mean girth $(61 \mathrm{~mm})$ of coffee was recorded from application of 50 $\mathrm{kg}$ NPS ha ${ }^{-1}+7.5 \mathrm{t}$ coffee husk compost $\mathrm{ha}^{-1}$. While, the lowest mean girth $(49 \mathrm{~mm})$ of coffee plant was recorded from control without application of any fertilizer. The maximum mean girth recorded for $50 \mathrm{~kg} \mathrm{NPS} \mathrm{ha-1}+7.5 \mathrm{t}$ coffee husk compost ha ${ }^{-1}$ might be due to more nutrients gained from both compost and NPS integrated fertilizers. Also reported, there was positive effect of application of combined amendments on stem diameter of coffee seedlings [7].

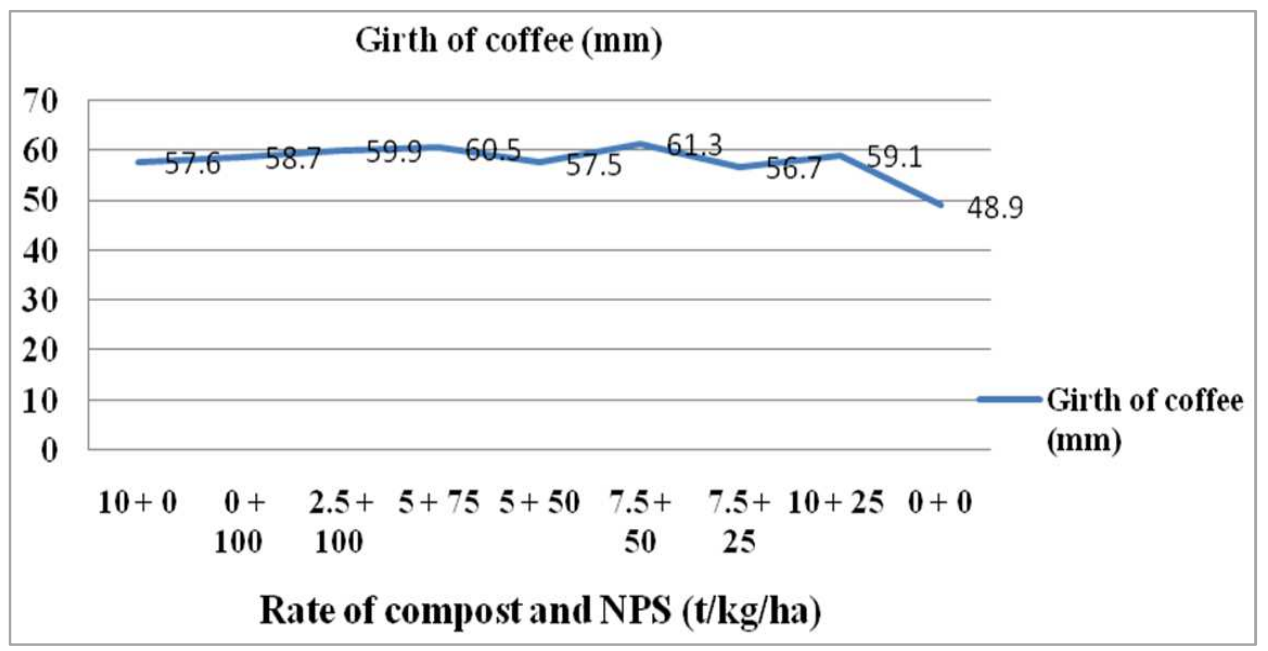

Figure 3. Effects of compost and NPS fertilizer on Girth.

\subsubsection{Number of Bearing Branches of Coffee}

The mean number of bearing branch of coffee was significantly $(p<0.05)$ affected by different rates of application of NPS fertilizer and coffee husk compost (Figure 4). The highest number of bearing branch 51 of coffee was obtained from application of $100 \mathrm{~kg}$ NPS $\mathrm{ha}^{-1}+2.5 \mathrm{t}$ decomposed coffee husk $\mathrm{ha}^{-1}$ followed by $10 \mathrm{t}$ coffee husk compost ha ${ }^{-1} 48$ and from treatment of $75 \mathrm{~kg} \mathrm{NPS} \mathrm{ha}^{-1}+5 \mathrm{t}$ coffee husk compost $\mathrm{ha}^{-1}$. While, the lowest number of bearing branch 32 of coffee was recorded from control
(Figure 4). The number of bearing branches of coffee was increased by $35.18 \%$ over the control. This might be due to nutrients applied to soils from integrated organic and inorganic fertilizers. Also, reported that bearing fruit load by thinning on selected branches assuming that the conclusions are valid for a whole tree [13]. However, lack of branch autonomy and movement assimilates from branches with lower fruit load to those with higher fruit load has been reported by [9]. 


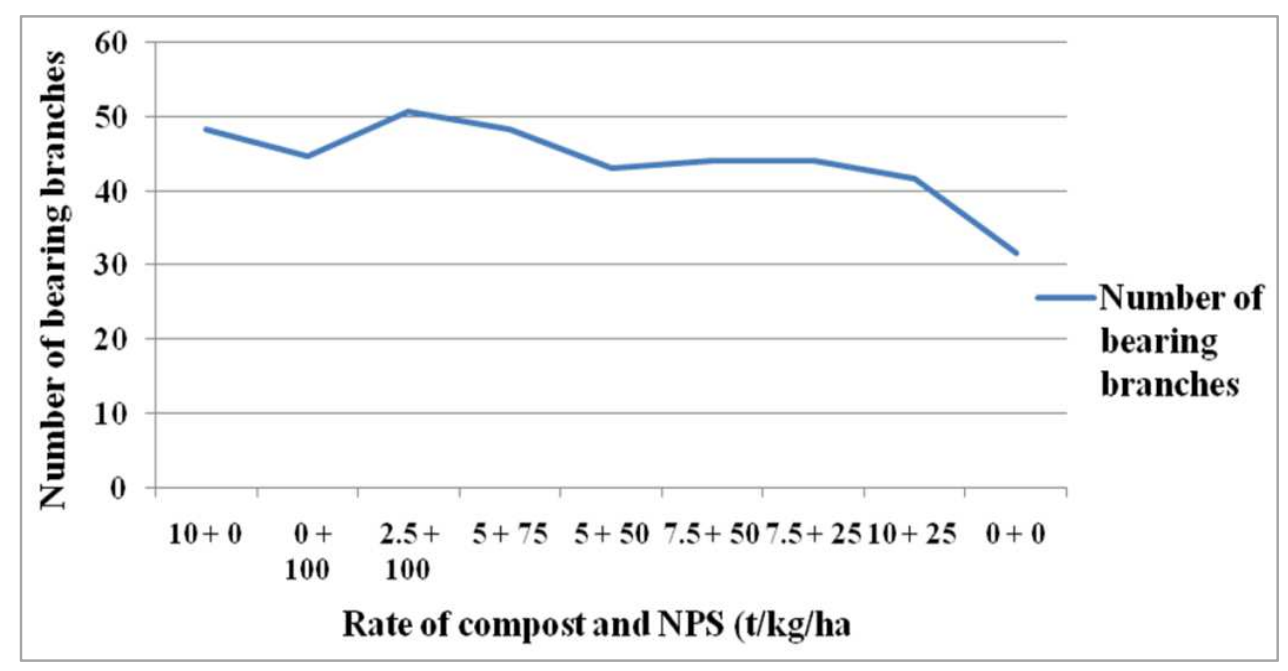

Figure 4. Effects of compost and NPS fertilizer on number of bearing branch.

\subsection{Effect of Coffee Husk Compost and NPS Fertilizer Rates on Yield of Coffee}

The effect of NPS fertilizer and decomposed coffee husk rates showed significant $(\mathrm{p}<0.05)$ difference on yields of coffee (Figure 5). The highest $3.98 \mathrm{t} \mathrm{ha}^{-1}$ mean yield was obtained with the combined application of $50 \mathrm{~kg} \mathrm{NPS} \mathrm{ha}^{-1}+$ $7.5 \mathrm{t}$ decomposed coffee husk compost ha ${ }^{-1}$ followed by mean $3.50 \mathrm{tha}^{-1}$ clean coffee yield recorded from application of 75 $\mathrm{kg} \mathrm{NPS} \mathrm{ha} \mathrm{a}^{-1}+5 \mathrm{t}$ decomposed coffee husk compost ha ${ }^{-1}$. The lowest $1.10 \mathrm{t} \mathrm{ha}^{-1}$ yield was obtained from the control without any fertilizer amendment (Figure 5). The combination of coffee husk compost at $7.5 \mathrm{tha}^{-1}$ and NPS fertilizer at $50 \mathrm{~kg}$ $\mathrm{ha}^{-1}$ application were the highest promise for coffee yields and about $64.70 \%$ coffee yield increase over the control. The highest yield from compost integrated with NPS fertilizer over the control might be attributed to extraction of large quantity of mineral nutrients of coffee crop from sufficient available nutrients supplied to soil by compost and blended fertilizers. Similarly, stated that incorporation of organic and inorganic fertilizers improved soil physical property and nutrient availability that may have a direct effect on coffee crop growth and yield attributes [3]. Combined applications of coffee husk compost and NPS chemical fertilizers are more effective than sole application of coffee husk compost or NPS blended fertilizers for sustainable coffee productivity enhancement. The incorporating combination of coffee husk compost and blended NPS fertilizers in the soil not only improved the nutrient status, but also resulted in good physical conditions of the topsoil and thus, significantly favored optimum shoot and root growth parameters and thus, enhanced nutrient use efficiency by the coffee crop with ultimate increased coffee yield and coffee crop productions. Similarly, also reported that coffee yields can only be enhanced and sustained by the addition of integrated form of compost and mineral fertilizers [33].

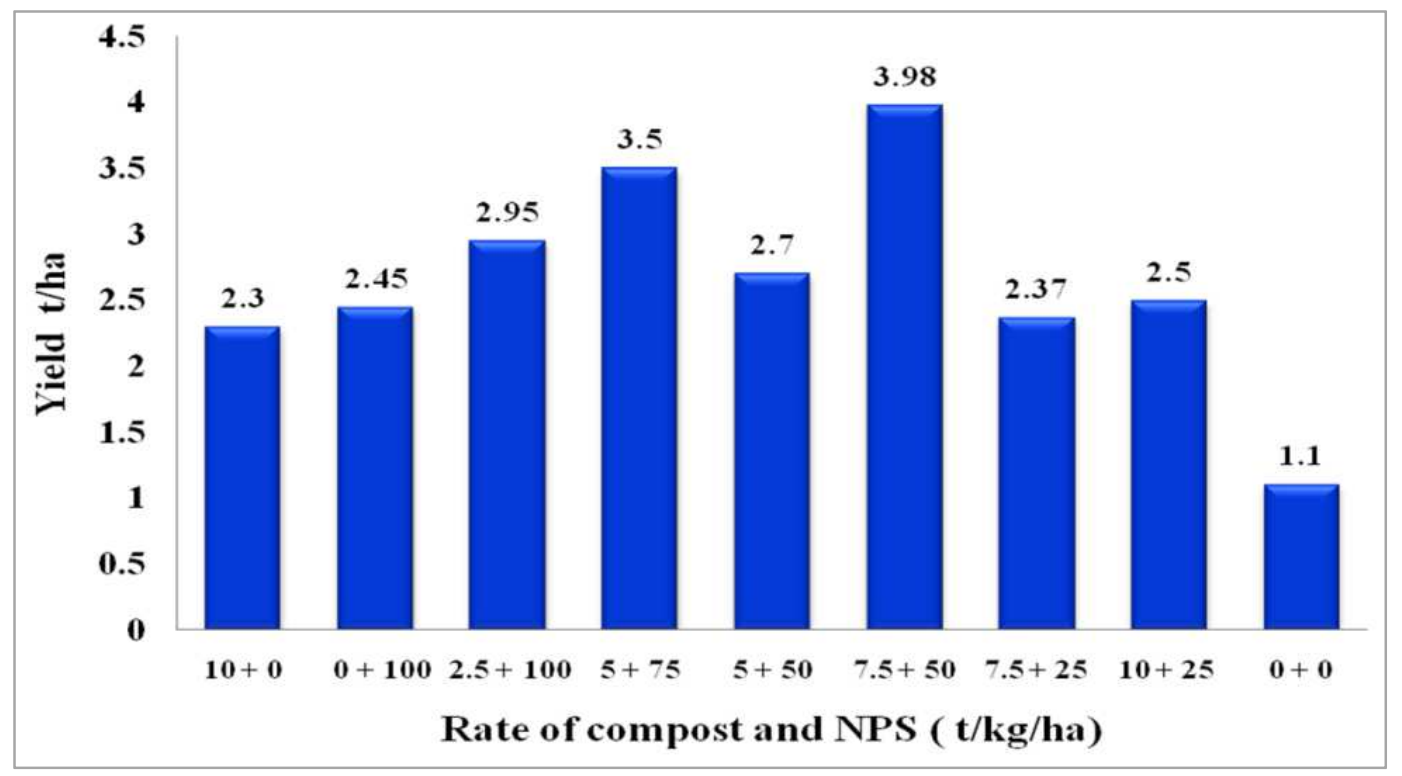

Figure 5. Effects of compost and NPS fertilizer on coffee yields. 


\section{Conclusions}

Integrated application of NPS fertilizer and decomposed coffee husk compost with different rates improved yield and yield components coffee. Whereas, the combination of decomposed coffee husk compost at $7.5 \mathrm{t} \mathrm{ha}^{-1}$ and NPS fertilizer at $50 \mathrm{~kg} \mathrm{ha}^{-1}$ leads in better yield and yield component of coffee crop. In the area of study Application of local available coffee husk compost and blended NPS fertilizer could be one option to reduce the yield gap. The use of $7.5 \mathrm{t} \mathrm{ha}$ ${ }^{1}$ decomposed coffee husk compost and $50 \mathrm{~kg} \mathrm{ha}^{-1}$ of NPS fertilizer can be the best alternative integrated soil fertility management option in place of the sole application of inorganic fertilizers at study area tentatively. Nevertheless, in order to give conclusive recommendation further research studies are needed for more soil types and coffee crop varieties.

\section{References}

[1] Adi, A. J., Noor, Z. M., 2009. Waste recycling: Utilization of coffee grounds and kitchen waste in vermi-composting. Bio Resource Technology, 2, 1027-1030.

[2] Agriculture Growth Program, 2013. From sample blended fertilizers to ample yields. Retrieved from http://ethioagp. org/from sample blended fertilizers to ample yields.

[3] Anteneh Netsere, TayeKufa and Tesfaye Shimber, 2015. Review of Arabica Coffee Nursery Management Research in Ethiopia. Journal of Biology, Agriculture and Healthcare, 13, 2224-3208.

[4] Agricultural Transformation Agency (ATA), 2013. Status of soil resources in Ethiopia and priorities for sustainable management. Nirobi, Kenya.

[5] Bart, M., Seneshaw T, and Yaw. N., 2014. Structure and performance of Ethiopia's coffee export sector, Addis Ababa, Edited book Published by Ethiopian Development Research Institute and International Food Policy Research Institute in Ethiopia strategy support program, 33p.

[6] Berhanu Tsegaye, Ali Mohammed, Tesfaye Shimber, Yehenew Getachew and Essubalew Getachew, 2015. Impact of sun drying methods and layer thickness on the quality of highland Arabica coffee varieties at Limmu; South western Ethiopia. Basic Research Journal, 1, 12-20.

[7] Bikila Takala, 2018. Effects of Lime and Compost on acidic Soil Amelioration and Growth of Coffee (Coffea Arabica L.) Seedlings at Haru, West Wollega. M.Sc. Thesis Submitted to School of Graduate Studies of Jimma University College of Agriculture and Veterinary Medicine, Department of Natural Resource Management.

[8] Chauhan, R., Hooda and Tanga, A., 2015. Coffee: The Backbone of Ethiopian Economy. Indian International journals of economic plants, 2, 082-086.

[9] Chaves A. R. M, Martins, S. C. V, Batista, K. D, Celin E. F, and Da Matta, F. M., 2012. Varying leaf-to-fruit ratios affect branch growth and dieback, with little to no effect on photosynthesis, carbohydrate or mineral pools, in different canopy positions of field-grown coffee trees, https://www.Sciencedirect.com/science/journal, 77, 207-218.
[10] Chemura, Abel, 2014. The growth response of coffee (Coffea Arabica L.) plants to organic manure, inorganic fertilizers and integrated soil fertility management under different irrigation water supply levels. International Journal Recycling Organic Waste Agriculture, 3, 1-9.

[11] Central Statical Agency (CSA), 2018. Area and production of major crops in the Federal democratic republic of Ethiopia central statistical agency agricultural sample survey, 1, 1-117.

[12] Fekadu Shemekite, Brandon, M. G. Franke, I. H., Praehauser, B., Insam, H. and Fassil Asefa, 2014. Coffee husk composting: An Investigation of the Process Using Molecular and Nonmolecular Tools. Waste Management, 34 (3): 642-652.

[13] Franck N, Vaast P, Génard M, and Dauzat J., 2006. Soluble sugars mediate sink feedback down- regulation of leaf photosynthesis in field-grown (Coffea arabica. L.) Tree Physiology, 4, 517-525.

[14] Gershuny Grace, 2011. Compost, Vermicompost, and Compost Tea: Feeding the Soil on the Organic Farm. White River Junction, VT: Chelsea Green Publishing.

[15] Gezahegne Barecha, Fikre Lamessa and Mulatu Wakjira, 2011 Exploring the suitability of coffee pulp compost as growth media substitute in greenhouse production. International Journal Agriculture Research, 6, 255-267.

[16] HBOADO (Haru Bureau of Agriculture Development Office), 2018.

[17] IFPRI (International Food and Policy Research Institute), 2010. Fertilizer and Soil Fertility Potential in Ethiopia. Constraints and opportunities for enhancing the system.

[18] Madeleine I., Peter S., Tim T. and Tom V., 2005. Agrodok no. 8: The preparation and use of compost. Agronomic Foundation, Wagenningen, Digigrafi, the Netherlands.

[19] Ministry of Agriculture and Natural Resource (MoAN R), 2013. Ethiopia is transitioning into the implementation of soil test based fertilizer use system. www.moa.gov.et/documents.

[20] Muluneh Siraj, 2018. Effects of Blended NPSB fertilizer rates on Growth yield and yield related traits of Potato (Solanum Tuberosum L.) Varieties under Irrigation in Degem. M.sc. thesis Submitted to School of Plant Sciences Haramaya University.

[21] Nguyen Anh Dzung, Tran Trung Dzung, and Voi Thi Phuong Khanh, 2012. Evaluation of Coffee Husk Compost for Improving Soil Fertility and Sustainable Coffee Production in Rural Central Highland of Vietnam, Journal of Resources and Environment, 3, 77- 82.

[22] SAS Institute Inc. 2013. SAS 9.3 Macro Language: Reference. Cary, NC: SAS Institute.

[23] Shiferaw Hailu, 2014. Digital soil mapping: Soil fertility status and fertilizer recommendation for Ethiopian agricultural land (Conference paper) Addis Ababa, Ethiopia.

[24] Solomon Endris, 2006. Accelerated composting of coffee processing by products: an organic option for soil fertility management in the coffee based cropping system of south western Ethiopia. Proceeding of $21^{\text {st }}$ International scientific conference on coffee science (ASIC), Montpelier, France, 1084-1089p. 
[25] Steel, R. G. D. and Torrie, J. H., 1980. Principles and procedures of statistics. A biometrical approach, 2nd Edition, Mc Graw-Hill Book Company, New York. Agricultural science, 1, 252.

[26] Taye Kufa, 1998. Response of Arabica coffee (Coffea arabica L.) to various soil fertility management. Thesis presented to the school of graduate studies Haramaya University of Agriculture. In partial fulfillment of the requirement for the Degree Master of science in agriculture (Agronomy), Haramaya, Ethiopia. 137p.

[27] Tenaw W, Husni, M. H., Anuar., A. R. and Zaharah, A. R., 2006. Effect of coffee bean residues and time on soil nitrogen availability. Malaysia Journals of Soil Science, 10, 53-65.

[28] Tolera Gemechu and Gebremedin Alemu, 2015. Opportunities and constraints of coffee production in West Hararghe Zone, Ethiopia. Journal of Agricultural Economics and Rural Development, 2, 54-59.

[29] TraThi thong, 2013. Compost Effect on plant Growth. M.sc. A thesis submitted to University of Adelaide.

[30] USDA (United States Department of Agriculture), 2018. Coffee world markets and trade foreign agricultural service in USA.

[31] Vanlauwe B, Bationo A, Chianu J, Giller K. E, Merck R, Mokwunye U, Ohiokpehai O, Pypers P, Tabo R, Smaling E,
Woomer P. L. and Sanginga. N., 2010. Integrated soil fertility management: Operational definition and consequences for implementation and dissemination. Out on Agriculture, 39, $17-24$.

[32] Wadt, P. G. S., 2011. Diagnosis of foliar and recommendation of fertilization for commercial crops. Conference forum, Rio Branco, 32, 50.

[33] Wairegi, L. W. I, van Asten P. J. A, Giller K. E and Fairhurst, T., 2014. Banana coffee system cropping guide. Africa Soil Health Consortium, Nairobi.

[34] Waseem, M., Ali, A., Tahir, M and Mehmood, K., 2013. Mitigate effect of diverse use of nitrogen sources on bulk density, organic matter and grain yield of hybrid maize. Pakistan Journal of Animal and Plant Sciences, 23, 900-905.

[35] Zebene Mikru and Wondwosen Tena. 2008. Potentials and Constraints of Nitisol and Acrisol. 209-216p. Coffee Diversity and Knowledge. Proceedings of National Workshop Four 67 Decades of Coffee Research and Development in Ethiopia, 14-17 August 2007, Addis Ababa (Ghion hotel), Ethiopia.

[36] Zelleke Gete, Getachew Agwgnehu, Dejene Abera and Shahid Rashad, 2010. Fertilizer and Soil Fertility Potential in Ethiopia: Constraints and opportunities for enhancing the system. Working Paper, International Food Policy Research Institute. http://www.Ifpri.org/sites/default/files/publications/Ethiopiana gsectorwp_soil.pdf. 